\title{
UK Renal Registry 16th Annual Report: Appendix E Methodology for Estimating Catchment Populations of Renal Centres in England and Wales for Dialysis Patients
}

\section{Introduction}

Providing accurate centre-level incidence and prevalence rates for patients receiving renal replacement therapy (RRT) in the UK was limited until the 13th Annual Report by the difficulty in estimating the catchment population from which the RRT population was derived. One reason for this was that the geographical boundaries separating renal centres are relatively arbitrary and dependent upon a number of factors including referral practice, patient choice and patient movement. Previously, incidence and prevalence rates had been calculated at Local Authority/Primary Care Trust/Health Board level for which denominator data were available, but not at renal centre level.

UK Renal Registry (UKRR) Annual Reports prior to the 13th suggested an estimate of the size of the catchment populations. These were extrapolated figures originally derived from data in the 1992 National Renal Survey undertaken by Paul Roderick.

The purpose of this document is to present an estimate of the dialysis catchment population for all renal centres in England and Wales. The document also contains a methodological description and discussion of the limitations of these estimates. The previous three UKRR Annual Reports contained estimates for English renal centres using the same methodology as outlined here but using 2001 Census data and 2007 prevalent dialysis patients and has been explained in detail elsewhere [1]. The methodology has now been repeated using data from the 2011 Census in order to obtain more up to date estimates and also to include renal centres in Wales.

\section{Methods}

The UK Renal Registry database of the incident dialysis population between 1st January 2008 and 31st December 2012 was used to estimate the size of each renal centre's catchment population. This used the postcode and centre for each individual starting RRT on dialysis.

Polygons were constructed to define an area around the geographical location of each dialysis patient. The lines of the polygons, representing the boundaries between areas, were drawn such that they were equidistant between adjacent patients, creating a map of non-overlapping polygons covering the entire area of England and Wales. This method produces Thiessen polygons which have the property that all locations within each polygon share the same nearest dialysis patient [2].

The polygons of all patients attending the same renal centre were combined to create the catchment area for that centre. The catchment area for one centre might comprise of multiple unconnected polygons as a result of adjacent patients attending different renal centres. The Office for National Statistics (ONS) map of 2011 Census merged wards contains population estimates for England and Wales divided into 8,546 wards. This was overlaid on the map of renal centre catchment areas, enabling the proportion of each ward's area covered by each of the renal centre catchment areas to be calculated. Each ward's population was then allocated to the renal centres in proportions equal to the overlaid areas. Summing these proportions of populations across all of the Census wards for each renal centre produced the estimates of the total catchment population at each centre.
C 2014 S. Karger AG, Basel

$1160-2110 / 14 / 1254-0327 \$ 38.00 / 0$

Accessible online at: www.karger.com/nec
UK Renal Registry, Southmead Hospital, Southmead Road,

Bristol, BS10 5NB, UK

Email: renalregistry@renalregistry.nhs.uk 


\section{Results}

The estimated dialysis catchment populations for renal centres in England and Wales are shown in Table E.1 and Table E.2 respectively. Table E.1 also displays the estimates contained in the previous three annual reports for comparison.

\section{Discussion}

These results show estimates for the size of the catchment areas for each of the renal centres in England and Wales.

There are some limitations to these results. The first is that the ward allocated to each renal centre was based upon dialysis patients only. Therefore it is possible that non-dialysis patients may come from a different catchment population. This is more likely where a renal centre provides specialist services and especially likely for patients undergoing renal transplantation. The catchment population for renal transplant patients will depend largely upon the distribution of workload between the referral centre and the transplanting centre for pre-transplant work-up, donor nephrectomy workup and post-transplant care (including if and when care is returned to the referring centre).

After calculating the population estimates it was discovered that the number of incident dialysis patients at Plymouth in 2012 had been under-reported. If the missing patients had been included, an additional Thiessen polygon would have been constructed for each of them, potentially increasing the overall catchment area, and therefore population, for Plymouth. The magnitude of the reduction in the calculated catchment population caused by the under-reporting is difficult to accurately estimate as it depends on the location of the missing

Table E.1. Estimated dialysis catchment populations of English renal centres based upon firstly mid-2007 and secondly 2011 ONS Census ward population estimates (rounded to nearest 1,000)

\begin{tabular}{|c|c|c|c|c|c|}
\hline Centre & Mid-2007 estimate & 2011 estimate & Centre & Mid-2007 estimate & 2011 estimate \\
\hline B Heart & 725,000 & 738,000 & Leeds & $1,647,000$ & $1,670,000$ \\
\hline $\mathrm{B}$ QEH & $1,624,000$ & $1,699,000$ & Leic & $2,318,000$ & $2,436,000$ \\
\hline Basldn & 408,000 & 415,000 & Liv Ain & 290,000 & 484,000 \\
\hline Bradfd & 579,000 & 652,000 & Liv RI & $1,199,000$ & $1,000,000$ \\
\hline Brightn & $1,195,000$ & $1,297,000$ & M RI & $1,469,000$ & $1,531,000$ \\
\hline Bristol & $1,571,000$ & $1,439,000$ & Middlbr & $1,012,000$ & $1,004,000$ \\
\hline Camb & $1,266,000$ & $1,158,000$ & Newc & $1,106,000$ & $1,121,000$ \\
\hline Carlis & 314,000 & 321,000 & Norwch & 793,000 & 787,000 \\
\hline Carsh & $1,916,000$ & $1,913,000$ & Nottm & $1,138,000$ & $1,088,000$ \\
\hline Chelms & 466,000 & 510,000 & Oxford & $1,680,000$ & $1,690,000$ \\
\hline Colchr ${ }^{\mathrm{a}}$ & & 299,000 & Plymth $^{\mathrm{b}}$ & 476,000 & 470,000 \\
\hline Covnt & 870,000 & 892,000 & Ports & $2,003,000$ & $2,024,000$ \\
\hline Derby & 647,000 & 703,000 & Prestn & $1,512,000$ & $1,493,000$ \\
\hline Donc & 214,000 & 410,000 & Redng & 805,000 & 910,000 \\
\hline Dorset & 725,000 & 862,000 & Salford & $1,420,000$ & $1,490,000$ \\
\hline Dudley & 415,000 & 442,000 & Sheff & $1,489,000$ & $1,372,000$ \\
\hline Exeter & $1,028,000$ & $1,089,000$ & Shrew & 391,000 & 501,000 \\
\hline Glouc & 575,000 & 587,000 & Stevng & $1,088,000$ & $1,204,000$ \\
\hline Hull & 987,000 & $1,020,000$ & Sthend & 316,000 & 317,000 \\
\hline Ipswi & 562,000 & 399,000 & Stoke & 897,000 & 890,000 \\
\hline Kent & $1,163,000$ & $1,224,000$ & Sund & 589,000 & 618,000 \\
\hline L Barts & $1,680,000$ & $1,830,000$ & Truro & 412,000 & 413,000 \\
\hline L Guys & $1,154,000$ & $1,082,000$ & Wirral & 521,000 & 572,000 \\
\hline L Kings & 970,000 & $1,171,000$ & Wolve & 606,000 & 669,000 \\
\hline L Rfree & $1,504,000$ & $1,518,000$ & York & 505,000 & 492,000 \\
\hline L St G & 585,000 & 797,800 & England & $51,050,000$ & $53,399,000$ \\
\hline L West & $2,227,000$ & $2,399,000$ & & & \\
\hline
\end{tabular}

Contains National Statistics data (C) Crown copyright and database right 2013

Contains Ordnance Survey data (C) Crown copyright and database right 2013

${ }^{a}$ Mid-2007 estimates calculated before Colchester became a separate renal centre

${ }^{\mathrm{b}}$ The 2011 catchment population for Plymouth may be too low (see main text of appendix for more details) 
Table E.2. Estimated dialysis catchment populations of Welsh renal centres based upon 2011 ONS Census Ward population estimates (rounded to nearest 1,000)

\begin{tabular}{lrlr}
\hline \multicolumn{1}{c}{ Centre } & 2011 estimate & Centre & 2011 estimate \\
\hline Bangor & 218,000 & Swanse & 885,000 \\
Cardff & $1,420,000$ & Wrexm & 240,000 \\
Clwyd & 190,000 & Wales & $\mathbf{2 , 9 5 3 , 0 0 0}$ \\
\hline
\end{tabular}

Contains National Statistics data (C) Crown copyright and database right 2013

Contains Ordnance Survey data (C) Crown copyright and database right 2013

patients relative to other patients at Plymouth and renal centres nearby.

Despite these limitations, this is the most valid methodology to date to estimate the size of the catchment populations for renal centres in England and Wales. The results of this analysis allow the UKRR to calculate estimates of the incidence and prevalence rates of renal replacement therapy at renal centre level, rather than only at PCT/HB level.

These results also provide other opportunities for study of the catchment populations. The ONS provides data on gender, age and ethnicity of the population at ward level. It should be possible to use this information to consider centre differences in the demographics of patients commencing or receiving RRT with adjustment for the catchment population characteristics.

\section{Acknowledgements}

Thanks are expressed to Andrew Judge for calculating these catchment populations for the UK Renal Registry.

\section{References}

1 Judge A, Caskey FJ, Welton NJ, Ansell D, Tomson CR, Roderick PJ, BenShlomo Y: Inequalities in rates of renal replacement therapy in England: does it matter who you are or where you live? Nephrol Dial Transplant. 2012 Apr;27(4):1598-1607 Nephron Dial Transplant. 2012 Apr;27(4): 1598-1607. doi: 10.1093/ndt/gfr466. Epub 2011 Aug 30

2 Boots BN: Voronoi (Thiessen) Polygons (Concepts and Techniques in Modern Geography); Norwich: Geo Books, 1986 